\title{
News from the IAG
}

\section{0th Anniversary Meetings}

A series of meetings was convened by the IAG in December 2000 to commemorate the 50th anniversary of the IAG. The Executive, Regional Chairs and Presidents of Member Associations met and considered future strategic directions for the Association. They and others contributed to the third in a series of meetings on a United Nations' project developing a Research Agenda on Ageing for the 21st Century (RAA-21). The third element to mark the occasion was a half-day meeting of the IAG and other NGOs to discuss strategies for having input to the Second UN World Assembly on Ageing to be held in Spain in April 2002. A special IAG Presidential Award was made to Charles Studer, who has worked energetically in support of the activities of the IAG over many years. The venue was the Salsomaggiore Therme which provided generous accommodation and wonderful Tuscan fare for delegates. Travel grant assistance was provided by Novartis Foundation for Gerontology. The next column from the IAG will include a full account of the proceedings of the various deliberations.

\section{IAG Manual of Operating Procedures: A Synopsis}

A tangible initiative to mark the 50th anniversary of the establishment of the IAG will result from the reviewing and updating of the association's Manual of Operating Procedures. Revisions primarily reflect practices that have evolved over time and become part of operational procedures. IAG Council, by majority vote, normally approves changes to the existing manual. This approval will be sought at the 2001 IAG Council meetings at the
World Congress in Vancouver. Feedback on the draft was sought through representatives of member associations present at the 50th anniversary meetings held in Salsomaggorie, Italy, before preparing the final draft. There was widespread support for the draft and the minor suggestions for alteration will be included in the final draft. Further comments are welcome and can be directed to the author via e-mail to iag@flinders.edu.au. A brief synopsis is included here to enable wider consultation and the entire document should be available on the IAG website www.cas.flinders.edu.au/iag.

The governance of the International Association of Gerontology is prescribed in a set of bylaws. These were originally written in French and registered in Belgium in 1950, when the IAG was established. An English translation was approved by Council at the XIIIth Congress in New York (USA) in July 1985. This translation - referred to hereafter as 'The Bylaws' - can be found as Appendix VII, by E. Busse and G.L. Maddox, in N.W. Shock's: The International Association of Gerontology: A Chronicle 1950 to 1986 [Springer, 1988].

According to Article 26 of the bylaws: A Manual of Operating Procedures of the Association will be submitted by the Executive Committee for Council approval and constitute an appendix to Association bylaws. The manual is advisory only and is intended as a guide to desirable practice regarding the duties of the Officers of the Association; dissemination of information on actions by the Executive Committee, and planning and implementation of the International Congresses. The council will periodically review and approve by majority vote of those present and voting, changes in the existing manual.

The draft revision of the Manual of Operating Procedures (MANUAL) incorporates procedures devised in 1989 and 1993 and presented to congresses in Acapulco

\begin{tabular}{ll}
\hline KARGER & ( ) 2001 S. Karger AG, Basel \\
0304-324X/01/0471-0060\$17.50/0 \\
$\begin{array}{l}\text { Fax +4161306 1234 } \\
\begin{array}{l}\text { E-Mail karger@karger.ch } \\
\text { www.karger.com }\end{array}\end{array}$ & $\begin{array}{l}\text { Accessible online at: } \\
\text { www.karger.com/journals/ger }\end{array}$
\end{tabular}


and Budapest, respectively. Procedures have been rewritten to make them more generic and to delete obsolete information. An attempt was made to consolidate information about similar topics in a single section, to provide more comprehensive coverage and enable better access to it.

The MANUAL also incorporates amendments agreed during Council Meetings of the IAG in Adelaide in 1997. Decisions were taken there to enhance IAG activities and to facilitate the smooth running of the IAG, its Secretariat and the World Congresses. The manual begins with a brief history of the Association and description of the key IAG symbols, i.e. the logo, flag and presidential medallion, and protocol for their use. It then describes the role of the IAG in its consultative status to the United Nations NGO Committee on Aging. A representative for the IAG is charged with providing, in coordination with the Executive Committee, appropriate forms of collaboration with bodies of the General Assembly, the Program on Aging, or other agencies and networks of the UN system. This role of the IAG is complementary to its role as a potential cosponsor for other major international activities on aging, e.g. participation in the Second World Assembly on Aging slated for 2002.

A central component of the MANUAL is a description of the roles of the five honorary office-bearers of the Association. The President, Secretary General/Vice President, Treasurer, Past-President, and President-Elect together comprise the IAG Executive. This team works together during and between World Congresses to promote gerontology on the international stage and communicate with the four regions. International communication is achieved via the IAG newsletter, a regular column in Gerontology and the IAG website. The Executive also plays a vital role in monitoring and expanding the membership of the IAG, which currently stands at 63 .

The MANUAL outlines accepted practice on holding various meetings of the IAG and awarding the Busse and Presidential prizes. It includes a section on the link with Gerontology, the IAG's principal professional journal outlet, which began in the mid-1980s and has been revitalized by the current President and Secretary General. A large component of the MANUAL is concerned with planning and implementing World Congresses. Consistent with the bylaws, matters pertaining to the pursuing activities within the four regions are not prescribed in the MANUAL. Nonetheless, it is expected that regions report regularly to the President, have their bylaws on the IAG website, hold a regional congress on a 4-year cycle falling mid-way between World Congresses, and provide a conduit by which associations in their region communicate with, or consider joining, the IAG.

In summary, the Manual of Operating Procedures at once provides a record of key historical milestones of the IAG and a resource for those concerned with the day-today activities of the IAG. It also provides guidance for future Office Bearers and the regions on how to approach tasks of concern to all engaged in promoting gerontology and geriatrics worldwide.

\section{Looking Ahead to the 2009 World Congress}

Without detracting from the impending 2001 Congress in Vancouver in July or the one to be held in Rio de Janeiro in 2005, it is time to start thinking about the 2009 Congress. At the time of writing, the IAG Secretariat has received three statements of intent to host the 19th Congress of the IAG. These have come from the French Gerontological Society, the Hong Kong Association of Gerontology, and the Federation of Korean Gerontological Societies. Full written proposals will be received and decided upon by a vote of the entire Council of the IAG at the second Council Meeting in Vancouver.

For information of societies looking ever further into the future, this is what a bid to host a World Congress typically includes:

- A formal invitation from the relevant organisation(s)

- Information regarding congress venue and facilities

- A broad statement of the theme(s) and content of the scientific program

- Previous experience or expertise to stage major scientific events

- Indications of probable sources of support for the event

Gloria Gutman, President of the Vancouver Congress or Norton Sayeg, President of Congress to be held in Brazil, would no doubt be an excellent source of recent wisdom on preparing successful bids. 